\title{
Spontaneous rupture of primary splenic angiosarcoma: a case report and literature review
}

\author{
Yun-Fei Duan, Yong Jiang, Chuan-Xing Wu and Feng Zhu*
}

\begin{abstract}
Background: Primary angiosarcoma of the spleen is a rare mesenchymal malignant tumor of vascular origin often with a poor prognosis, due to its high metastatic potential. This disease often presents with atraumatic rupture and lethal hemorrhage.

Case presentation: We report a case of a 65 -year-old man who presented with abdominal pain, anemia, thrombocytopenia, and palpable abdominal mass with unstable blood pressure. Laparotomy revealed a huge actively bleeding spleen, thus splenectomy was performed. Some liver metastasis foci were also found during the procedure. Histopathology diagnosis of the removed spleen was primary splenic angiosarcoma. The patient was discharged on the 10th day post operation with no complication.

Conclusions: Splenic angiosarcoma should be considered one of the differential diagnoses in patients with spleen parenchymal lesions. Definitive diagnosis requires laparotomy followed by splenectomy. In the majority of the patients with spleen angiosarcoma, metastatic diseases have already occurred at the time of laparotomy, so splenectomy is an approach more for diagnostic purpose rather than curative purpose.
\end{abstract}

Keywords: Spleen, Neoplasm metastasis, Sarcoma

\section{Background}

Primary angiosarcoma of the spleen is an extremely rare malignancy, the pathogenesis of which is unknown, with high metastatic potential and a very poor prognosis. This aggressive disease usually presents in adults in their sixth to seventh decade. The reported median survival rates range from 4.4 to 14 months [1,2]. These mesenchymal tumors can easily be neglected and splenic rupture is the most frequently manifestation at the time of diagnosis. We report a case of spontaneous splenic rupture due to angiosarcoma in a 65-year-old man.

\section{Case presentation}

A 65-year-old man was admitted with diffuse abdominal pain and distention. The pain was constant and dull, and started 2 hours prior to admission with no obvious inducible factor. The patient's past medical history was unremarkable except mild weight loss during the recent 5 months. Physical examination revealed a palpable abdominal mass in the left upper abdominal quadrant with

\footnotetext{
*Correspondence: dahe1971@163.com

Department of Hepatobiliary Surgery, The Third Affiliated Hospital of Soochow University, 185 Juqian Street, Changzhou, Jiangsu 213000, China
}

tenderness, and the patient's hemodynamic condition was unstable with systolic arterial blood pressure only $85 \mathrm{mmHg}$ and heart rate 110 beats/minute. After initial fast fluid resuscitation $(1,000 \mathrm{ml}$ hetastarch $130 / 0.4$ $\mathrm{NaCl}$ ), the hemodynamic status of the patient became stable. Peripheral blood count revealed anemia (hemoglobin $10.0 \mathrm{~g} / \mathrm{dl}$ ) and thrombocytopenia (platelets $90 \times$ $10^{9} / \mathrm{l}$ ), but it did not reach disseminated intravascular coagulopathy. Results of other laboratory examinations had not been reported to us before the operation due to the emergency. Abdominal ultrasonography showed an enlarged spleen filled with irregular nodules, multiple hepatic solid lesions and moderate accumulation of peritoneal fluid. Abdominal paracentesis was performed with blood fluid aspirated from the peritoneal cavity. These findings were further confirmed by an abdominal computed tomography scan (Figure 1), demonstrating a heterogeneous, low-density signal within the splenic parenchyma, with variable degrees of contrast enhancement as well as intra-abdominal hemorrhage originating most possibly from the spleen. Meanwhile, there were multiple low-density lesions with enhanced rim in the liver. 


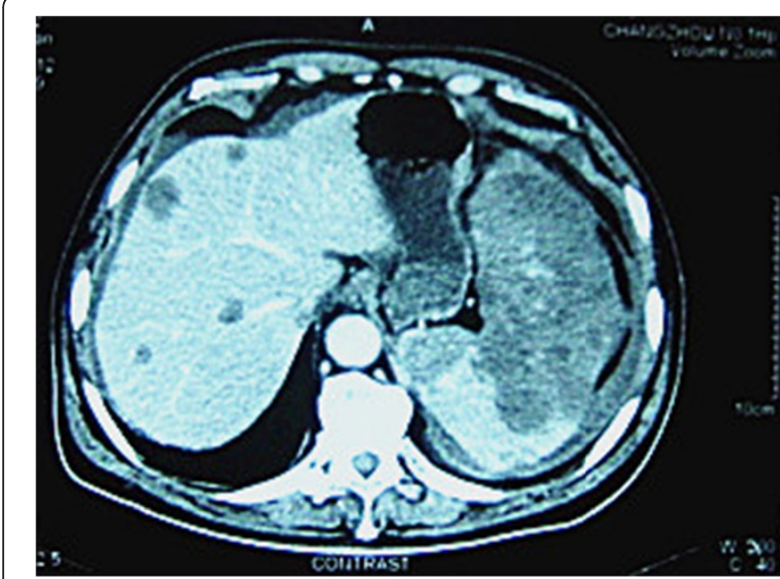

Figure 1 Enlarged spleen completely replaced by low-density tumor tissue and multiple hypervascular metastases in liver. Contrast-enhanced image in the portal venous phase computed tomography scan showing the enlarged spleen completely replaced by tumor tissue with low density and multiple hypervascular metastases in the liver with sizes varying from $5 \mathrm{~mm}$ to $2 \mathrm{~cm}$. Some free fluid around the liver and spleen was also found, indicating intraperitoneal hemorrhage.

Laparotomy revealed a huge spleen actively bleeding and an abnormal liver with several metastatic foci. We did observe a fissure of the capsule of the spleen with a size of $6 \mathrm{~cm}$ (length) $\times 2.5 \mathrm{~cm}$ (depth) in the lower pole of spleen. Two liters of blood had been collected from the peritoneal cavity. Splenectomy was performed. During the procedure, the patient received 4 units of concentrated red blood cells and 2 units of fresh frozen plasma.

The spleen was $1,650 \mathrm{~g}$ in weight, $19 \mathrm{~cm} \times 16 \mathrm{~cm} \times 11$ $\mathrm{cm}$ in size, with nodular appearance and bleeding. The pathology diagnosis of the excised spleen was angiosarcoma originating from the spleen (Figure 2). Immuno-

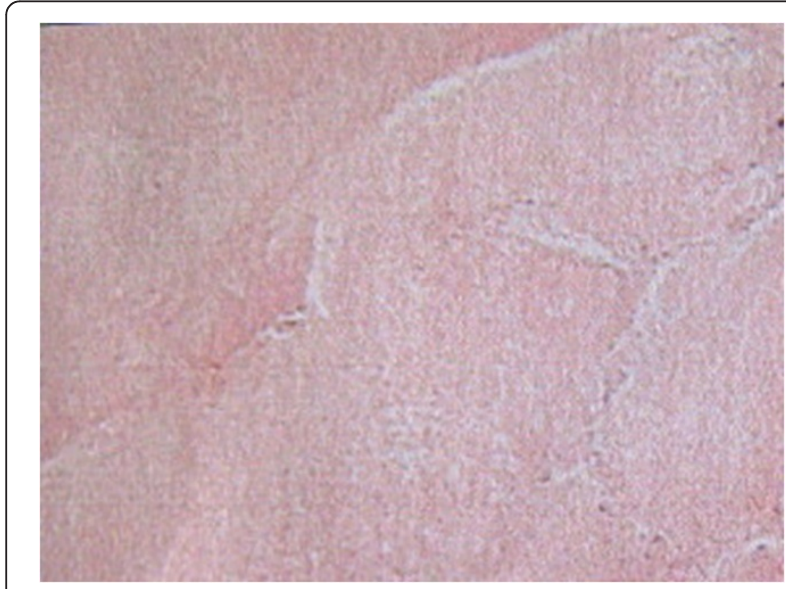

Figure 2 Histopathologic findings of the spleen angiosarcoma. Spindle tumor cells have replaced the normal red and white pulp in the spleen, whereas ecstatic vascular spaces lined with hypertrophied endothelial cells are apparent.

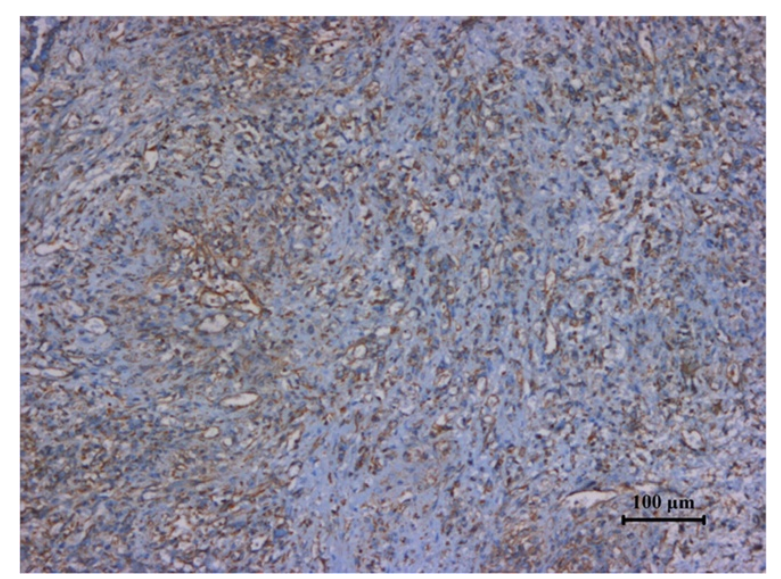

Figure 3 Specimen stained positive for vimentin.

histochemical staining was positive for vimentin (Figure 3), CD31 (Figure 4), CD34 (Figure 5), factor VIII (Figure 6), a1ACT (Figure 7) and SMA (Figure 8), and was negative for lysozyme (Figure 9). The Ki-67 proliferation index was less than 10\% (Figure 10).

\section{Discussion}

Angiosarcoma originated from the spleen is an extremely rare malignant tumor, which affects 0.14 to 0.25 per million people [3]. People at any age may develop this disease. The presentation age is between 14 months and 89 years. This neoplasm shows a slight male predominance [3-5]. We reviewed related literatures and summarized the data (Table 1).

Although the pathogenesis of this tumor is not clear, ionizing radiation, arsenic, vinyl chloride and chemotherapy for lymphoma have been implicated as causative factors $[18,19]$, and it has been reported that the angiosarcoma requires the existence of a benign pathology such as hemangioma or hemangioendothelioma

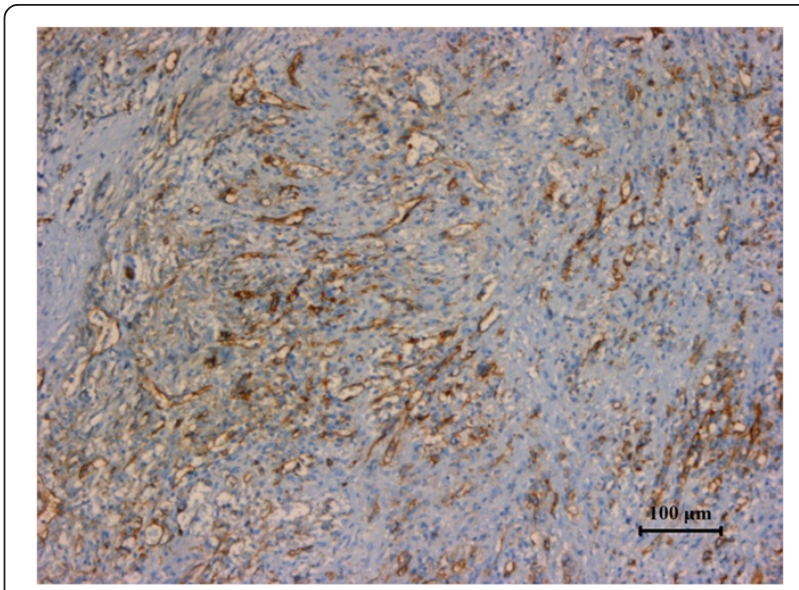

Figure 4 Specimen stained positive for CD31. 


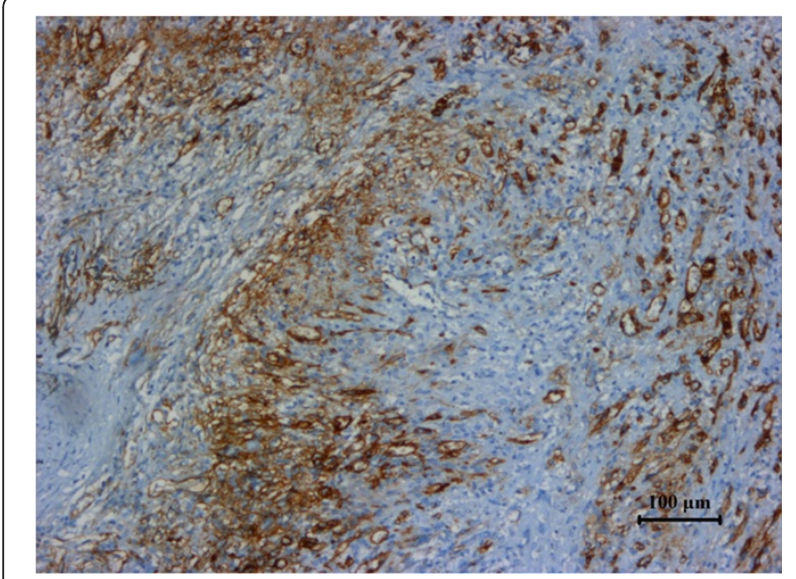

Figure 5 Specimen stained positive for CD34.

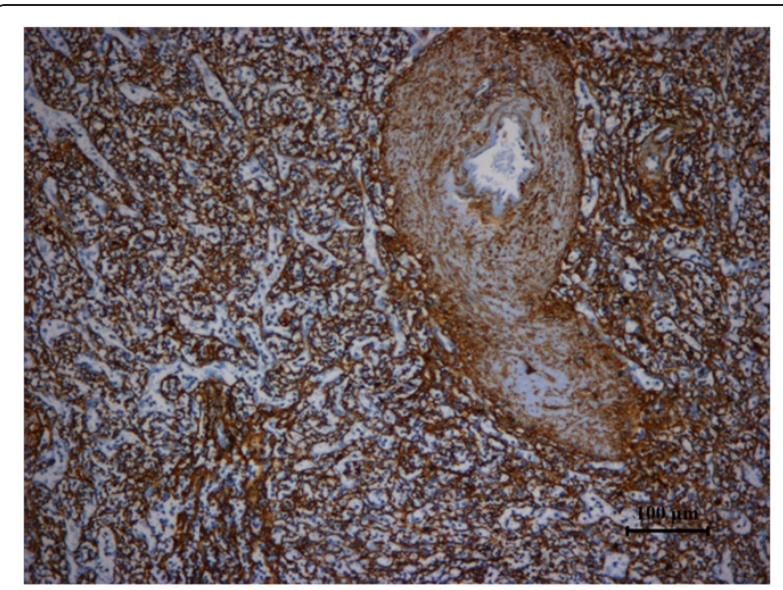

Figure 8 Specimen stained positive for SMA.

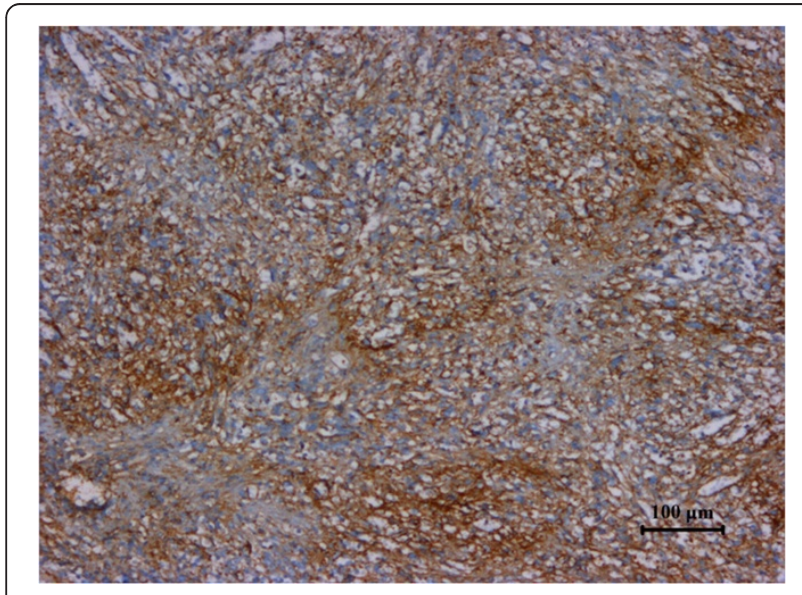

Figure 6 Specimen stained positive for factor VIII.

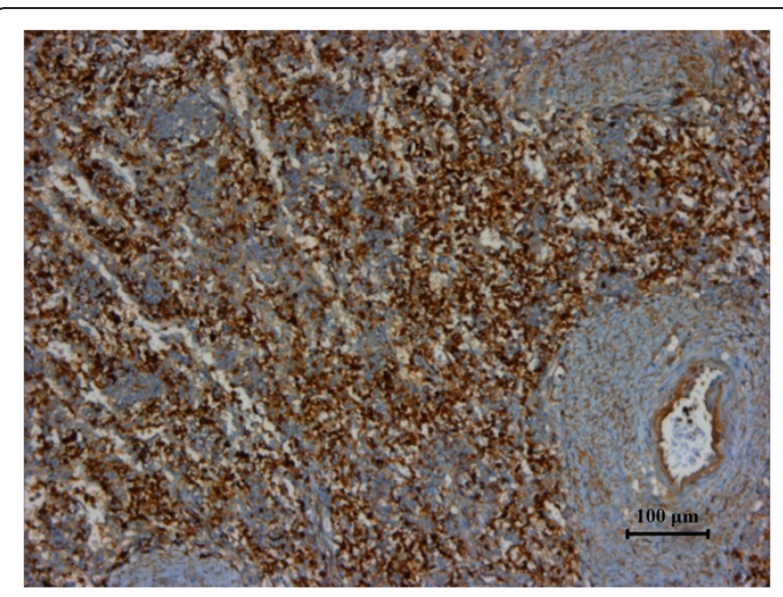

Figure 9 Specimen stained negative for lysozyme.

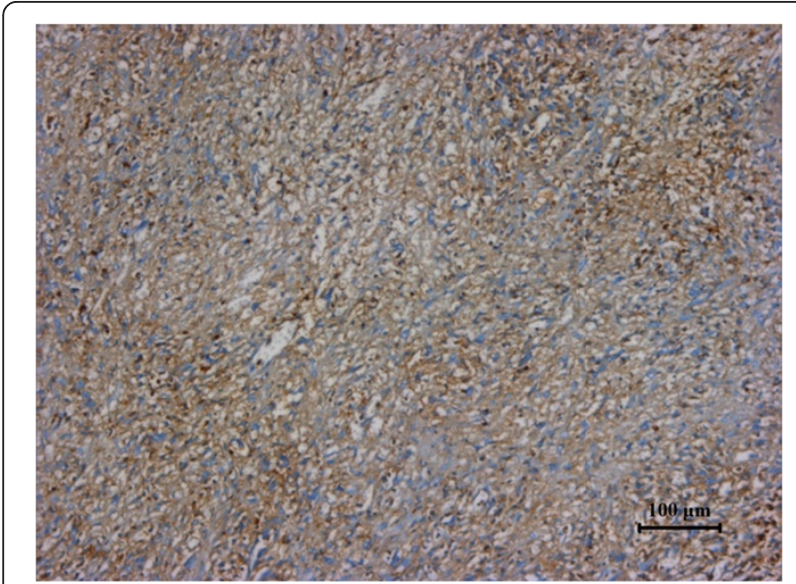

Figure 7 Specimen stained positive for a1ACT.

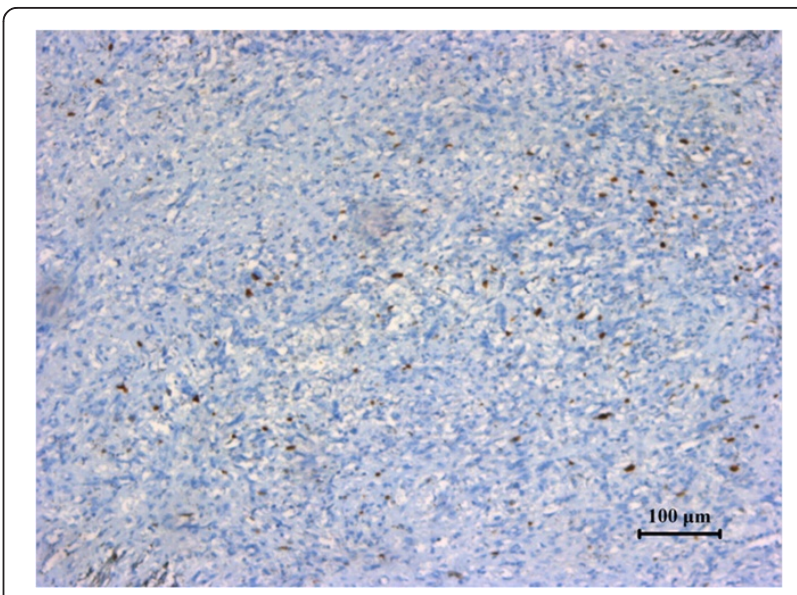

Figure $10 \mathrm{Ki}-67$ proliferation index less than $10 \%$. 
Table 1 Data of the published literatures regarding splenic rupture secondary to splenic angiosarcoma

\begin{tabular}{|c|c|c|c|c|c|c|c|}
\hline Gender & Age & Clinical manifestations & Laboratory result & Early metastasis & Treatment & Prognosis & Reference \\
\hline Female & 45 & $\begin{array}{l}\text { Left upper abdominal } \\
\text { pain and mass, shock }\end{array}$ & $\begin{array}{l}\text { Anemia, } \\
\text { thrombocytopenia }\end{array}$ & $\begin{array}{l}\text { Early multiple } \\
\text { metastases }\end{array}$ & $\begin{array}{l}\text { Splenectomy and } \\
\text { chemotherapy }\end{array}$ & $\begin{array}{l}\text { Died } 4 \text { months after } \\
\text { surgery }\end{array}$ & [6] \\
\hline Female & 79 & None & Anemia & No & Splenectomy & $\begin{array}{l}\text { Discharged on the 10th } \\
\text { postoperative day }\end{array}$ & [7] \\
\hline Female & 17 & $\begin{array}{l}\text { Shock, left upper } \\
\text { abdominal pain and mass }\end{array}$ & $\begin{array}{l}\text { Anemia, } \\
\text { thrombocytopenia }\end{array}$ & No & Splenectomy & $\begin{array}{l}\text { Disease-free of } \\
16 \text { months }\end{array}$ & [8] \\
\hline Female & 45 & $\begin{array}{l}\text { Left upper abdominal } \\
\text { pain }\end{array}$ & Thrombocytopenia & $\begin{array}{l}\text { Liver metastases after } \\
3 \text { months }\end{array}$ & $\begin{array}{l}\text { Splenectomy and } \\
\text { chemotherapy }\end{array}$ & $\begin{array}{l}\text { Died } 7 \text { months after } \\
\text { surgery }\end{array}$ & [9] \\
\hline Male & 57 & $\begin{array}{l}\text { Upper abdominal pain, } \\
\text { shock }\end{array}$ & $\begin{array}{l}\text { Anemia, } \\
\text { thrombocytopenia }\end{array}$ & Early liver metastases & Splenectomy & Died 1 day after surgery & [10] \\
\hline Female & 64 & $\begin{array}{l}\text { Fatigue, upper abdominal } \\
\text { pain }\end{array}$ & Thrombocytopenia & Early bone metastases & $\begin{array}{l}\text { Splenectomy and } \\
\text { chemotherapy }\end{array}$ & $\begin{array}{l}\text { Died } 4 \text { months } \\
\text { after surgery }\end{array}$ & [11] \\
\hline Male & 76 & $\begin{array}{l}\text { Upper abdominal pain, } \\
\text { shock }\end{array}$ & $\begin{array}{l}\text { Anemia, } \\
\text { thrombocytopenia }\end{array}$ & $\begin{array}{l}\text { Peritoneal and liver } \\
\text { metastases after } 4 \text { weeks }\end{array}$ & Splenectomy & $\begin{array}{l}\text { Died } 6 \text { weeks after } \\
\text { splenectomy }\end{array}$ & {$[12]$} \\
\hline Female & 37 & $\begin{array}{l}\text { Left upper abdominal } \\
\text { pain }\end{array}$ & Anemia & Liver metastases & $\begin{array}{l}\text { Splenectomy and } \\
\text { chemotherapy }\end{array}$ & $\begin{array}{l}\text { Died } 6 \text { months after } \\
\text { surgery }\end{array}$ & [13] \\
\hline Male & 53 & $\begin{array}{l}\text { Upper abdominal pain, } \\
\text { shock }\end{array}$ & $\begin{array}{l}\text { Anemia, } \\
\text { thrombocytopenia }\end{array}$ & Early liver metastases & Splenectomy & $\begin{array}{l}\text { Died } 7 \text { months after } \\
\text { surgery }\end{array}$ & [14] \\
\hline Female & 35 & $\begin{array}{l}\text { Upper abdominal pain, } \\
\text { shock }\end{array}$ & None & Early liver metastases & Splenectomy & Died 4 day after surgery & [15] \\
\hline Female & $\begin{array}{l}80 \text { and } \\
\text { over }\end{array}$ & Shock & Anemia & & Splenectomy & & {$[16]$} \\
\hline Female & $\begin{array}{l}\text { Middle } \\
\text { age }\end{array}$ & & & Early liver metastases & Splenectomy & & [17] \\
\hline
\end{tabular}

$[18,20]$. However, there was no evidence of any of these factors involved in our case.

Clinical presentation of splenic angiosarcoma is variable. Left upper abdominal pain is the most common symptom [5]. Other complaints include fatigue, weight loss, and anorexia. Splenomegaly is the most common physical examination finding [5]. Hepatomegaly and left upper quadrant mass are other two common findings. The most serious manifestation is splenic rupture, which often leads to fatal hemorrhage [21].

Laboratory examination can find cytopenia, leukocytosis, thrombocytosis and elevated erythrocyte sedimentation rate. Anemia and thrombocytopenia are presented in more than $50 \%$ cases $[3,11]$.

Imaging examinations are helpful for the differential diagnosis, although lacking accuracy. The most common ultrasonography findings are splenomegaly and ill-defined solid and cystic masses in the spleen with heterogeneous echotexture [22,23]. The areas of hemorrhage and necrosis within the tumors are frequently shown as cystic areas. Increased blood flow may be detected in the solid part of the masses on color Doppler images. Computed tomography may reveal an enlarged spleen with hypoattenuating or hyper-attenuating areas with punctate or massive calcification on plain computed tomography scan (without contrast agent infused) [24,25]. Areas with hyper-attenuation are likely to reflect acute hemorrhage. On contrast-enhanced computed tomography scans, the tumors may exhibit peripheral or heterogeneous enhancement similar to that of hepatic cavernous hemangiomas $[26,27]$. On magnetic resonance imaging, ill-defined nodular lesions with low or high signal intensity may be seen on both T1-weighted and T2-weighted images. High signal intensity on both T1-weighted and T2-weighted images is related to subacute hemorrhage or tumor necrosis, and low signal intensity is related to chronic hemorrhage or fibrosis within the tumor [28].

Biopsy is contraindicated in splenic angiosarcoma because of high risk of rupture. Histologic studies can therefore only be made after splenectomy. Microscopic examinations reveal freely anastomosing papillary and classical characteristic vascular channels lined by masses of endothelial cells [4]. Immunohistochemically, at least two vascular proliferation markers (CD31, CD34, and factor VII) plus at least one histiocytic differentiation marker (lysozyme and/or CD68) are required to makes the diagnosis [5].

This tumor has a high incidence of early metastasis, as reflected in the reported rates of between $69 \%$ and $100 \%$, with the most common sites being in the liver, lungs, bones or bone marrow, lymph nodes, gastrointestinal tract, brain and adrenal glands [3,5,29]. Our patient, however, had metastases in the liver.

Our case died 6 months after the surgery. Primary splenic angiosarcomas are very aggressive neoplasms, with a median survival of 5 months irrespective of 
treatment. Neuhauser and colleagues reported that 93\% of patients died with disseminated tumor within 29 months [5]. Early diagnosis with splenectomy can result in a much more favorable survival rate $[3,21]$, but it is very difficult.

\section{Conclusions}

Splenic angiosarcoma is very rare but has a poor prognosis. It may cause secondary spontaneous rupture, resulting in fatal hemorrhage, which should be paid sufficient attention. Immediate surgery is necessary but the outcome is still unsatisfactory. Attempts should be made to improve the outcome by developing new techniques.

\section{Consent}

Written informed consent was obtained from the patient for publication of this report and any accompanying images.

\section{Competing interests}

The authors declare that they have no competing interests.

\section{Authors' contributions}

$\mathrm{Y}-\mathrm{FD}$ and $\mathrm{FZ}$ participated in the clinical management of the patient and wrote the manuscript. YJ and C-XW carried out the pathological examination. Y-FD and FZ were involved in the final editing. All authors approved the final manuscript.

Received: 5 November 2012 Accepted: 16 February 2013 Published: 4 March 2013

\section{References}

1. Buckner JW 3rd, Porterfield G, Williams GR: Spontaneous splenic rupture secondary to angiosarcoma. J Okla State Med Assoc 1990, 83:211-213.

2. Montemayor P, Caggiano V: Primary hemangiosarcoma of the spleen associated with leukocytosis and abnormal spleen scan. Int Surg 1980 65:369-373.

3. Falk S, Krishnan J, Meis JM: Primary angiosarcoma of the spleen. A clinicopathologic study of 40 cases. Am J Surg Pathol 1993, 17:959-970.

4. Valbuena JR, Levenback C, Mansfield P, Liu J: Angiosarcoma of the spleen clinically presenting as metastatic ovarian cancer. A case report and review of the literature. Ann Diagn Pathol 2005, 9:289-292.

5. Neuhauser TS, Derringer GA, Thompson LD, Fanburg-Smith JC, Miettinen M, Saaristo A, Abbondanzo SL: Splenic angiosarcoma: a clinicopathologic and immunophenotypic study of 28 cases. Mod Pathol 2000, 13:978-987.

6. Stutz FH, Tormey DC, Blom J: Hemangiosarcoma and pathologic rupture of the spleen. Cancer 1973, 31:1213-1215.

7. Koutelidakis IM, Tsiaousis PZ, Papaziogas BT, Patsas AG, Atmatzidis SK, Atmatzidis KS: Spleen rupture due to primary angiosarcoma: a case report. J Gastrointest Cancer 2007, 38:74-77.

8. Manouras A, Giannopoulos P, Toufektzian L, Markogiannakis H, Lagoudianakis EE, Papadima A, Papanikolaou D, Filis K, Kekis P: Splenic rupture as the presenting manifestation of primary splenic angiosarcoma in a teenage woman: a case report. J Med Case Reports 2008, 2:133

9. Miyata T, Fujimoto Y, Fukushima M, Torisu M, Tanaka M: Spontaneous rupture of splenic angiosarcoma: a case report of chemotherapeutic approach and review of the literature. Surg Today 1993, 23:370-374.

10. Mayir B, Colak T, Dinckan A: [Spontaneous spleen rupture due to primary splenic angiosarcoma: a case report]. Ulus Travma Acil Cerrahi Derg 2007, 13:313-315

11. Raffel S, Hildebrandt B, Grieser C, Pahl S, Sturm I: Thrombocytopenia as first manifestation of splenic angiosarcoma. Ann Hematol 2010, 89:109-110.
12. Simansky DA, Schiby G, Dreznik Z, Jacob ET: Rapid progressive dissemination of hemangiosarcoma of the spleen following spontaneous rupture. World J Surg 1986, 10:142-145.

13. Maier A, Bataille F, Krenz D, Anthuber M: [Angiosarcoma as a rare differential diagnosis in spontaneous rupture of the spleen]. Chirurg 2004, 75:70-74.

14. Villedieu Poignant $S$, Mermet $L$, Bousquet A, Dupont P: [A rare cause of spontaneous hemoperitoneum]. Rev Med Interne 2000, 21:809-811.

15. Linan-Padilla A, Suarez-Grau JM, Valera Sanchez Z, Vazquez-Medina A, Docobo-Durantez F: [Spontaneous hemoperitoneum due to hemangiosarcoma of the spleen]. Cir Esp 2008, 84:171-172.

16. Sivelli R, Piccolo D, Soliani P, Franzini C, Ziegler S, Sianesi M: Rupture of the spleen in angiosarcoma: a case report and review of the literature. Chir Ital 2005, 57:377-380.

17. Winde G, Sprakel B, Bosse A, Reers B, Wendt M: Rupture of the spleen caused by primary angiosarcoma. Case report. Eur J Surg 1991, 157:215-217.

18. Sordillo EM, Sordillo PP, Hajdu SI: Splenic angiosarcoma. Am J Surg Pathol 1995, 19:119-120

19. Zwi LJ, Evans DJ, Wechsler AL, Catovsky D: Splenic angiosarcoma following chemotherapy for follicular lymphoma. Hum Pathol 1986, 17:528-530.

20. Alt B, Hafez GR, Trigg M, Shahidi NT, Gilbert EF: Angiosarcoma of the liver and spleen in an infant. Pediatr Pathol 1985, 4:331-339.

21. Autry JR, Weitzner S: Hemangiosarcoma of spleen with spontaneous rupture. Cancer 1975, 35:534-539.

22. Nahman B, Cunningham Jj: Sonography of splenic angiosarcoma. J Clin Ultrasound 1985, 13:354-356.

23. Vrachliotis TG, Bennett WF, Vaswani KK, Niemann TH, Bova JG: Primary angiosarcoma of the spleen - CT, MR, and sonographic characteristics: report of two cases. Abdom Imaging 2000, 25:283-285.

24. Reddy SC: Hemangiosarcoma of the spleen: helical computed tomography features. South Med J 2000, 93:825-827.

25. Kinoshita T, Ishii K, Yajima Y, Sakai N, Naganuma H: Splenic hemangiosarcoma with massive calcification. Abdom Imaging 1999, 24:185-187.

26. Ferrozzi F, Bova D, Draghi F, Garlaschi G: CT findings in primary vascular tumors of the spleen. AJR Am J Roentgenol 1996, 166:1097-1101.

27. Rabushka LS, Kawashima A, Fishman EK: Imaging of the spleen: CT with supplemental MR examination. Radiographics 1994, 14:307-332.

28. Thompson WM, Levy AD, Aguilera NS, Gorospe L, Abbott RM: Angiosarcoma of the spleen: imaging characteristics in 12 patients. Radiology 2005, 235:106-115.

29. Chen KT, Bolles JC, Gilbert EF: Angiosarcoma of the spleen: a report of two cases and review of the literature. Arch Pathol Lab Med 1979, 103:122-124.

doi:10.1186/1477-7819-11-53

Cite this article as: Duan et al:: Spontaneous rupture of primary splenic angiosarcoma: a case report and literature review. World Journal of Surgical Oncology 2013 11:53

\section{Submit your next manuscript to BioMed Central and take full advantage of:}

- Convenient online submission

- Thorough peer review

- No space constraints or color figure charges

- Immediate publication on acceptance

- Inclusion in PubMed, CAS, Scopus and Google Scholar

- Research which is freely available for redistribution 